\title{
データを計量する 社会を推論する
}

——新たな」手法が見せる社会科学と社会—

\section{佐藤 俊 樹*}

最近注目されている統計的因果推論やベイズ統計学は, 効果量（効果サイ ズ）の分析などとともに，社会学にも大きな影響をあたえうる．これらは基本 的な考え方ではウェーバーの適合的因果や理解社会学と共通しており，量的デ ータにもテキスト型データにも適用できる.

例えば, 統計的因果推論は個体レベルの因果の多様さを前提に, その期待值 として集団単位の因果効果を厳密に測定する方法であり, 一回性の事象にも理 論上は適用できる. 潜在的な結果変数と原因候補と全ての共変量の同時分布を 想定することで，適合的因果をより正確かつ一貫的に再定義したものにあたる. 理解社会学であれば, 主観的で仮説的な先入観をデー夕の客観的な情報を用い てくり返し修正していくべイズ更新として，再定式化できる.

こうした方法群は主観性と客観性の両面を同時にもっている。それゆえ, こ れらを通じて観察される社会の実定性もこの両面をつねにもつ.

キーワード : 統計的因果推論, ベイズ統計学, 理解社会学

\section{1 数理・計量手法の新たな展開}

社会科学では, 自然科学（理工学）との距離がつねに問題になってきた，そもそ も社会科学という言葉自体が, 社会を対象とする自然科学という意味をふくんでい る. それゆえ, 自然科学と社会科学がどうちがうのかは, 一貫して重要な論点にな ってきた。

特に方法の面で, その傾向は著しい. 社会科学の手法の多くは, 自然科学から輸 入されてきた. そのため, 自然科学の方法を社会に応用した科学, という性格を社 会科学はもちつづけてきた.

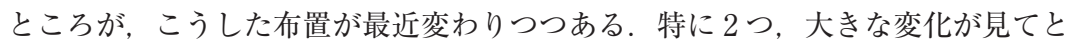
れる.

第 1 に, 従来, 自然科学の手法にはなじまない, 社会科学や人文学の固有な対象 とされてきた言葉や言説にも,「テキスト・マイニング」や「ビッグ・デー夕」と

* 東京大学大学院総合文化研究科教授 tsatou@waka.c.u-tokyo.ac.jp 
呼ばれる方法が進出してきた。 そして第 2 に, 社会的な因果の解明や意味的な理解 など,やはり社会科学や人文学に固有とされてきた方法論にも, 自然科学の方法が 進出してきている. 英語圈での KKV 論争，すなわち「計量分析対事例研究」の対 立はよく知られている.

$2 つ の$ 変化はもち万ん相互に関連しあっている. より目立つのは第 1 の方だが, より根底的なのは第 2 の方だと私は考えている。 その変化のあり様も従来とは変わ ってきている.

これまでも自然科学から新たな方法が輸入されてきた，一番の成功例は統計的検 定だろうが，「最先端」だと喧伝された手法や理論が全く使えなかった事例も少な くない.

現在の変化はこれとはかなりちがう。自然科学からの輸入というょりも, 自然科 学と社会科学に分化する以前にうまれた方法が, 自然科学のなかで数理的に形式化 されて，広く使われるようになり，それが社会科学にも導入されつつある。 そんな 経緯をたどっている。実は先ほど輸入の成功例としてあげた統計的検定にもそうい う面があり，だからこそ成功したとも考えられる（3 節参照）。

基本的な考え方では，これらは社会科学で使われてきた方法群と変わらない。 た

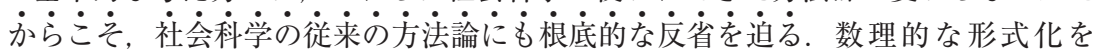
通じて，これまで十分に反省的でなかった部分が明らかになるからだ.

以下では, その一部を紹介し解説しながら, これらが社会科学, とりわけ社会学 に何をもたらすのかを述べていこう.

\section{2 「データ科学」とデータの代表性}

まず，第1の対象の変化について，すでに述べたように，こちらの方はそれほど 重大なものにはならないだろう.

例えば，いわゆる「デー夕科学」的手法，すなわち（a1）ネットなどに発信され た大量の呟きや言明（=「ビッグ・デー夕」）の分析によって, (b1) 適切な標本抽 出にもとづく社会調查や世論調查が代替できるわけではない。 この 10 年間で, そ の点はむしろはっきりした.

簡単にいえば，（a1）はデー夕収集作業の大部分を省ける．質問票の回答がネッ ト上に流れているようなものだからだ．だから費用の安さに利点をもち，データの 代表性で欠点をもつ. 2016 年のアメリカ大統領選挙でビッグ・デー夕による予測 が外れたのも，その影響が大きいのではないだろうか.

（b1）の利点と欠点はちょうどその反対になる，その意味で，両者はむしろ相補 的である。新聞記事や刊行図書などのテキスト型デー夕を用いる研究にも，もちろ んこの対照性はあてはまる，デー夕の代表性を重視しない研究であれば，言葉や言 説をあつかうものも，次第に「デー夕科学」的な手法にとって代られるだろう.

言説分析でもそうだ，具体的にいえば，（a2）ジャンルや資料空間をあらかじめ 
限定した言説分析よりも，(b2）そうした限定をできるだけ置かず，特定の言葉群 に注目して資料を博索するような言説分析の方が，実はデータの代表性ではすぐれ ている.

例えば,「○○の歴史社会学」的な研究では,「時代」や「社会」といった社会学 的な区分が実質的にそうした限定として使われてきた（遠藤 2006）。その点を考え れば,「時代」や「社会」をあらかじめ限定しない, それゆえ, 一見あまり社会学 的に見えない（b2）型の言説分析の方が，デー夕の代表性を反省的に主題化でき るが，発表される業績で効果を測った場合には，（a2）の方が費用対効果の点では 圧倒的に有利だ.

つまり，言説分析における（a2）と（b2）のちがいは，世論調査における（a1） と（b1）のちがいと同型である.（a）で（b）が代替できるわけではない. と同時 に，十分に（b）ではない研究は，(a) に吸収されていくだろう。これに関しては 別の論考ですでに検討しているので, 詳しくはそちらを参照してほしい（佐藤 2006, 2016 など).

こうしたデータの代表性の重要さは, 統計的因果推論のような新たな手法によっ てさらに大きくなっている.これについては9節で述べる.

\section{3 効果量と非心分布}

次に, 第 2 の方法の変化について. より重要で, 根底的になりうるのはこちらの 方だと思う．基本的な考え方では社会科学で使われてきた方法群と変わらない．だ からこそ，社会科学の従来の方法論にも根底的な反省を迫る。

1 節で述べたように, 統計的検定, 現在ではより広く「統計的誤差を考慮した判 断手法」といった方がよいが, それらにもそういう面がある. 日常的な判断の形式 を数理化することで量的な評価ができるようにしてあるが, 判断の論理自体は変わ りない.

統計的検定でいえば，基本は 2 種類の誤りのあつかいにある。これも実は，一定 の基準に準拠する全ての判断にあてはまる. 例えば生活保護などの社会福祉の受給 資格，いわゆる「不正受給」の問題でもそうだ，本当に生活保護を受けるべき状態 の人を「資格なし」とするのが第 1 種の䛊り，本当は受けるべき状態でない人を 「資格あり」とするのが第 2 種の誤りにあたる.

よく知られているように，第 2 種の誤りすなわち不正受給の可能性を減らそうと すれば，本当に受けるべき状態の人の多くが受給できなくなる．すなわち第 1 種の 誤りを犯す可能性が増える．2 種類の䛊りの確率はつねにトレード・オフになる.

それを数理的に形式化したのが, 統計的検定だと考えればよい.

統計的検定, より正確にいえばネイマン\&ピアソンの定理にもとづく現在の検定 では, (1)第 1 種の誤りの確率の上限（=有意水準）を設定した上で, (2)第 2 種の誤 りの確率ができるだけ小さくなる（=検出力ができるだけ大きくなる）ように，判 
定の基準值を定める. $「 0.05$ 点」などの大きさや片側検定／両側検定の使い分けも， これにもとづく．先ほどの社会福祉の受給資格の例で考えてもらえば，この定め方 が常識的で妥当なのもわかりやすいだろう.

現在の社会調査法の解説では, 第 2 種の誤りに関わる部分は大幅に省かれている. そのため,こうした日常的な判断との同一性にも気づきにくいが,「一様最強力」 や検出力関数などを理解する上では，第 2 種の誤りと非心分布の知識は欠かせない. 逆にいえば，その知識があれば，より日常的な判断に近い形で検定や推定を使える.

実際, 統計的誤差を考慮した判断としては, 現在では両側検定ではなく, 区間推 定の方が第一和選択となりつつある。ベイズ統計学の影響もそこには関わっている が (10 節参照)，これらは「効果量（効果サイズ） effect sizeの分析」と総称され る. 効果量の分析では第 2 種の誤りと非心分布の知識が必須になるが，それによっ てより自然で, 論理的に一貫した判断ができる. それゆえ, 従来の統計的検定に代 わって，こちらの方が主流になりつつある.

社会学者にとって身近な例をあげれば，いわゆる「カイ 2 乗（による独立性の） 検定」でもそうだ．カイ 2 乗の独立性検定はよく使われるが，実際の使い方には問 題が多いものも少なくない．例えば，2つの変数の間で「関連性がある」と主張し たい場合も，「関連性がない」と主張したい場合も，しばしば同じ有意水準（0.05 や0.1）が使われる.

厳密にいえば，通常の形でカイ 2 乗検定を使うのは，「関連性がある」と主張し たい場合に限った方がよい，なぜなら，「2つの変数に関連性がない場合にピアソ ンのカイ 2 乗值がしたがう確率分布」がカイ 2 乗分布だからである（背理法なので こうなる)，それに対して，「2つの変数に関連性があううう場合にカイ 2 乗值が二 般的にしたがう確率分布」は非心カイ 2 乗分布である (永田 2003 など). 非心カ イ 2 乗分布はカイ 2 乗分布をその一部にふくむ.

したがって，非心カイ 2 乗分布を使えば，「関連性がある」と主張したい場合も 「ない」と主張したい場合も，統一的に判断できる，具体的には，2 変数の関連性 を示す母集団効果量，例えばクラメルの連関係数 $\mathrm{V}$ を非心カイ 2 乗分布で区間推定 すればよい（南風原 2014：75-7 参照)。近似解になるが，これが一番筋のよいやり 方だろう。「関連性がない」と主張したい場合にもカイ 2 乗検定を使うのであれば, 次善の策として, 大きな有意水準 $(0.9 や 0.95)$ で判定する方が合理的だ.

逆にいえば，例えば父主職と本人現職の関連性などで「関連性がある/ない」の 両方を主張する可能性がある場合，どちらの場合も同じ有意水準でカイ 2 乗検定を 使うのは適切ではない．社会科学的な判断として，「本当はあるのにないと判定す る」誤りと「本当はないのにあると判定する」誤りと，どちらをより重くみている かに関して，一貫性を欠くことになるからだ，私自身は授業では，福島第一原発の 30 キロ圈内／圈外と甲状腺ガンの発見／非発見のクロス表の事例で解説している. これも「関連性がある/ない」の両方の主張で同じ有意水準が使われているが，人 命が関わるときにどちらの誤りをより重視するかは, 文字通り critical になる（橋 
本 2014 など参照).

その点でも, 非心カイ 2 乗分布を用いた区間推定はより自然な方法だといえる. 現在では， R な゙を使えば，非心カイ 2 乗分布も計算できる. 数理的な手段や知識 が発達した結果, 日常的な判断や社会科学の論理により近い形で, より厳密な計量 手法が使えるようになったわけだ.

こうした面での水準向上は今後, 緊急性の高い課題になってくるだろう. 社会学 者による日本語の解説書で，この水準まで視野にいれたものとしては杉野（2017） がある。

\section{4 反事実的因果の統計的推論}

実はこれと同じような変化が, より大規模に，社会科学全体を巻き込む形で起き ている.「統計的因果推論」と呼ばれる手法の導入だ.

ここ 10 年ほどで, 日本語圈の社会学でも統計的因果推論はかなり知られてきた (中澤 2017 など). 方法論的な考察もいくつか書かれているが, 必ずしも適切な理 解がなされていないように思う。少し込み入った議論になるので, 私の方が誤解し ている可能性もあるが，それもふくめて，社会学にとって避けて通れない課題なの で，参考にはなるだろう。

佐藤（2017）でも述べたが, 統計的因果推論の基本的な考え方は, M. ウェーバ 一の「適合的因果構成 adequate causation (adäquate Verursachung)」と同じであ る（Weber $1906=1965 ）$ ）その点で，やはり伝統的な手法だももう少し詳しくいう

と, 統計的因果推論は適合的因果をより明確に形式化した上で, それを厳密に測定 する条件群を明確にし，その手段を具体的に提示した。

統計的因果推論の出発点は, 「反事実的な counterfactual」因果定義にある。こ

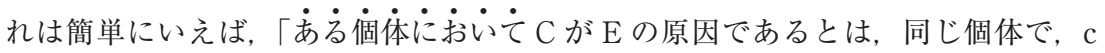
（=変数 Cに該当）である下では $\mathrm{c}$ でない下よりも $\mathrm{E}$ が生じやすい，といえること である」とする考え方だ. 哲学では今も多くの議論があるが，科学的な研究では現 在これが共通了解になりつつある (Weiberg 2013=2017 など). ウェーバーの適合 的因果もこの定義を用いている（Ringer 1997，佐藤 2017）.

「反事実的」と呼ばれるのは,「cである下」と「cでない下」のどちらか一方は, 現実には起きていない事態だからだ，同じ個体において，「cである」状態と「cで ない」状態が同時に成立することはない，それゆえ，反事実的因果は直接観察する ことができない。これを「因果推論の根本問題」(Holland 1986: 947) という。ウ エーバーも適合的因果を厳密に定義する場合には, 反実仮想を表す接続法 II 式（英 語の仮定法過去）を用いている（Weber 1906：287=1965：207-8など）.

統計的因果推論の新しさは，その点をふまえた上で，この反事実的に定義される 因果を集団単位で代理測定する方法を示したところにある。より正確にいえば, ［1］個体レベルの反事実的な因果を明確に定義した上で，[2]それが集団単位での 
測定にどう現れてくるかを理論的に明らかにした.

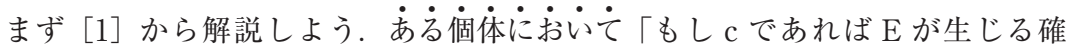
率」と「もし c でなければ $\mathrm{E}$ が生じる確率」をそれぞれ想定する. 条件付き確率 の形で表せば, 前者は $\mathbf{P}(\mathbf{E} \mid \mathbf{C})$, 後者は $\mathbf{P}(\mathbf{E} \mid \neg \mathbf{C})$ にあたる。 もし個体レベルでの 因果 unit-level causation が C と E の間にあれば, その個体では「cである下では c でない下よりも $\mathrm{E}$ が生じやすい」.つまり，その個体では $\mathbf{P}(\mathbf{E} \mid \mathbf{C})>\mathbf{P}(\mathbf{E} \mid \neg \mathbf{C})$, す なわち $\mathbf{P}(\mathbf{E} \mid \mathbf{C})-\mathbf{P}(\mathbf{E} \mid \neg \mathbf{C})>\mathbf{0}$ が成り立つ.

この $\mathbf{P}(\mathbf{E} \mid \mathbf{C})-\mathbf{P}(\mathbf{E} \mid \neg \mathbf{C})$ を「個体レベルでの因果効果」という。これが 0 ならば, 個体レベルでの因果は存在しない. ただし, 先ほど述べたように, 同じ個体で「c である」と「cでない」が同時に成立することはないので，この值自体は測定でき ない. また, この条件付き確率の式は, 㛜密には因果の必要条件にあたる. すなわ ち, C と E の間に反事実的因果があれば， $\mathbf{P}(\mathbf{E} \mid \mathbf{C})-\mathbf{P}(\mathbf{E} \mid \neg \mathbf{C})>\mathbf{0}$ が成立するが, $\mathbf{P}(\mathbf{E} \mid \mathbf{C})-\mathbf{P}(\mathbf{E} \mid \neg \mathbf{C})>\mathbf{0}$ が成立するからといって, C と $\mathrm{E}$ の間に反事実的因果があ るとは限らない (8 節参照).

\section{5 個体レベルの因果と平均因果効果}

重要なのは [2] の方である，反事実的因果は直接観察できないので，個体レべ ルの因果効果も実際には測定できない.けれども, 特定の集壬単位であれば, 一定 の条件群がみたされれば，その集団での（個体レベルの因果効果の）期待值（平 均值） $\mathbf{E}[\mathbf{P}(\mathbf{E} \mid \mathbf{C})-\mathbf{P}(\mathbf{E} \mid \neg \mathbf{C})]$ は具体的なデータから計算できる（星野 2009: 35-9, 岩崎 2015: 69-71 など). この集団単位の期待值を「平均因果効果」と呼ぶ.

その意味で, 代理測定になる。「無作為割当て」や「ランダム化比較実験」,「傾 向スコアの利用」などの手法は，この平均因果効果を具体的なデータから計算でき る条件（9節参照）をみたすためのものである.

例えば無作為割当ての実験であれば，被験者をCにあたる処置をする群としな い群にわけて，それぞれで $\mathrm{E} の$ 出現比率を調べる。その際に, 被験者をどちらの 群にするかは無作為に決める。この操作を「無作為割当て」という. 無作為割当て をすれば, 2 つの群の出現比率の差, すなわち「cである下で $\mathrm{e}$ (=変数 $\mathrm{E} に$ に該当)

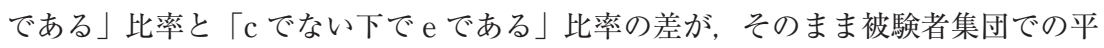
均因果効果になる.

逆にいえば, 具体的なデータから平均因果効果を求めるためには, 測る際に一定 の条件をみたす必要がある。 なぜならば，一般には個体レべルの因果効果のあり方 は多様であり，そのため，どのような因果のあり方をしている個体が調査対象にな るかによって, 測定された結果が変わってくるからである.

わかりやすくするために, 原因候補 C も結果 $\mathrm{E} も 2$ 值だとしよう。この場合, 個体レベルでは(1)「cであれば e であるが, c c でなければ e でない」個体だけでな く, (2)「cであってもなくても e である」個体も, (3)「cであってもなくても e で 


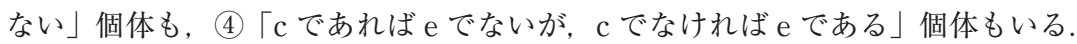
こうしたちがいが生じるのは，「e になる」要因は c だけでなく，Cにも E にも影 響する他の先行変数群があるからである。これらの変数を「共変量 covariate」と 呼ぶ（星野 2009：7），共変量は各個体の「cである/でない」と「eである／でな い」にさまざまに作用している。

それゆえ, 集団単位で調べると,「cである」群と「cでない群」に(1)〜(4)の個体が どのくらいふくまれるかによって，「cであり e である」比率と「cでなく e である」 比率が変わってくる (わかりやすい数值例は岩崎 2015: 77 など参照). 例えば, もし $\lceil\mathrm{c}$ である」群に(2)が多くふくまれていると, (2)は個体レベルでは $\mathbf{P}(\mathbf{E} \mid \mathbf{C})=\mathbf{P}(\mathbf{E} \mid \neg \mathbf{C})$ だから，Cと Eの間に因果はないが，「eである」ではあるので，集団単位のデー 夕では $\mathbf{P}(\mathbf{E} \mid \mathbf{C})>\mathbf{P}(\mathbf{E} \mid \neg \mathbf{C})$ になりやすい.

無作為割当てはそれを回避する手段にあたる。「cである」（=処置する）かどう かを, 無作為に決めることによって,「cである」群と「cでない」群で, 未夈知の変 数まで京く市共変量のあり方が群同士では同じになる. その結果, 4 種類の個 体が「cである」群と「cでない」群に必ず同じようにふくまれる，それゆえ，デ ータでの $\mathrm{E}$ の出現比率の差が, その集団における平均因果効果に一致する.

ところが, 社会調査などの調査観察データでは, こうした操作ができない. その ため,「cである」群と「c でない」群で共変量のあり方が同一になるような工夫が 必要になる，例えば「ランダム化比較実験」は，社会内で無作為割当ての実験をし て結果を調べる.「傾向スコアの利用」では, 全で்共変量のあり方を 1 つの傾向 スコア（=「cである」へのなりやすさ）に集約して，その值が同じ同士の組み合 わせで（実際には值が近い下位群間で）「cであり e である」比率と「cでなく e で ある」比率の差をとり，それを傾向スコアの分布で重みづけて集計する.

通常の重回帰の要因統制と比べると, 重回帰では調べた範囲だけで他の変数の影 響を調整する。 また, 反事実的状態での共変量の働き方に関して, かなり強い仮定 を置かないと,「cである」群と「cでない」群で全ての共変量のあり方が同じにな っているとはいえない. そのため, 偏回帰係数は一般には平均因果効果とは一致し ない（星野 2009: 51-5). 重回帰はもともと目的変数の值を効率よく予測する手法 であり，因果の特定に用いるのは一種の転用だと考えた方がよいだろう（8～9 節 も参照).

\section{6 「適合的因果」との関連}

こうした形で整理すると, ウェーバーの適合的因果との関係もはっきりする.

一回性の事象もあつかえる因果特定の方法論を組み立てる上で, ウェーバーは 2 つの大きな問題にぶつかった：［I：特定の原因候補の働き方をあらかじめ決めず に因果関係を同定する］ことと，［II：無数の原因候補のなかで特定の因果を識別 する]ことである（Weber 1906: 283=1965: 202-3 など）．Ｉは J. v. クリースが提 
案した確率的因果論の枠組みを使って解決された（佐藤 2017）。—どちらの方向 に働くかは, その原因候補 Cが「ある」場合に結果 E がどのくらい生じたか（= $\mathbf{P}(\mathbf{E} \mid \mathbf{C}))$ と, 「ない」場合にどのくらい生じたか $(=\mathbf{P}(\mathbf{E} \mid \neg \mathbf{C}))$ とを, (同じ条件 の下で）それぞれ数えあげて比べればよい。 それで $\mathbf{P}(\mathbf{E} \mid \mathbf{C})>\mathbf{P}(\mathbf{E} \mid \neg \mathbf{C})$ であれば, Cと Eの間に因果関係があるとする.

それに対して, II の識別問題はより深刻だった. 現時点では未知の先行変数, つ まり原理的には観察できるが, 具体的には観察できない変数まで考慮する必要があ るからだ。こちらに関しては，「cである下では c でない下よりも $\mathrm{E}$ が生じやすい」 や「もし C が生じていなければ Eも生じていない」といった反事実的命題を「法 則論的知識 nomologische Wissen」として用いる, とした. それによって, C と E 以外の変数の影響がないことになる（この命題は I についての仮定でもある）.

そして, 具体的な事態にどんな法則論的知識があてはめられるかは, 「経験則 Erfahrungsregelnによる」とされた. すなわち, 日常的な経験的知識を援用して 买市り的に仮定される, とウェーバーは述べている（Weber $1906=1965$, 佐藤 2017).

統計的因果推論の術語系に戻せば, I の答えはそのまま因果効果の考え方に通じ る.ただし, 先ほど述べたように, 具体的なデータから因果効果を求めるには, 共 変量すなわち C と E にともに関わる先行変数の影響を同じにしなければならない. これは他の全ての原因候補からの影響を調整することにほかならない.

反事実的な因果定義それ自体では，この問題は生じない.「同じ個体でもし〜」

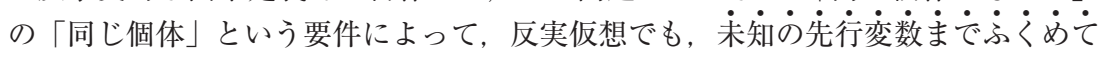
全ての他の要因が同じ值をとることが自動的に含意されるからだが，だからこそ， 個体レベルの反事実的因果は直接観察できない.

それゆえ, 次善の策として, 特定の集団単位でのその平均值である平均因果効果 $\mathbf{E}[\mathbf{P}(\mathbf{E} \mid \mathbf{C})-\mathbf{P}(\mathbf{E} \mid \neg \mathbf{C})]$ を求める. それを通じて個体レベルの因果のあり方も間接的 に推測できるが (不偏推定值なので, 実質的な意義を見出すかどうかは平均 2 乗誤 差の仮定の置き方次第になる, Holland 1986: 949 参照), 平均因果効果をデータか ら計算するには,「cである」と「cでない」の間で共変量の働き方を何らかの方法 で同一にしなければならない. そうやって初めて, その集団において「この結果 $\mathrm{E}$ の原因は（疑似的 spurious ではなく）本当にCである」といえる1）.

そういう形でI とIIが結びついていることを, 統計的因果推論は示した. より正 確にいえば，I と II は平均因果効果の特定という同じ問題に回収されることを示し た.

こう整理すると，「法則論的知識」と法則科学の「法則」が全く別物であること も明瞭になる。もし「c ならば必ず e になる」のような演繹的法則がわかっている のならば, そもそも I の問題は生じない. もし具体的なデータから「cである下で は c でない下よりも e になりやすい」といった法則性を導き出すのであれば, まず II を解決しなければならない. そのためには, 例えば「共変量は群同士では全て同 
一」という仮定を，すなわち他の先行変数群に関する法則論的知識をもちこまざる をえない. 法則論的知識はむしろ因果同定の前提条件にあたるものだ.

統計的因果推論はそれをさらに一歩進めた形になっている.

無作為割当てされた実験データなら, 特定の集団に限れば「他の先行変数は群同 士では全て同一」の状態が成立する，それによって集団単位ではII を解決でき，そ れによってIも解決できる, 一方, 個体レベルの因果に関しては, 不偏推定值しか わからない. もしあえて一個体での因果を特定しようとすれば，ウェーバーが述べ たように，「cである下では c でない下よりも $\mathrm{E}$ が生じやすい」といった反事実的 命題を, 法則論的知識として直接仮定するしかない.

それに対して, 調査観察データでは「他の先行変数は群同士では全て同一」の状 態になるよう，何らかの手段で調整するか，たまたまその状態にあるデー夕を見つ け出す必要がある。 そのための方法は現在さかんに研究されているが，傾向スコア の定義からわかるように,「これら以外には共変量はない」などの形で, 他の先行 変数に関する仮定を置かざるをえない.つまり, その仮定を法則論的知識として天 下り的に導入することで, 集団単位では II と I が解決できる. 個体レベルの因果に 関しては，実験データと同じことになる.

\section{7 因果的記述の必要性と限界}

以上の点をふまえて，よくある疑問を整理しておこう.

まず，統計的因果推論への反論として，これは集団単位の因果関係をあつかうも ので，それ以外の因果的な記述や影響関係にはあてはまらない，といわれてきた. それ以外のものとしては,「結果の原因 the causes of the effects」や「生成メカニ ズム generating mechanism」(Goldthorpe 2007a, 石田 2012 など), あるいは「個 体の多様性」の影響などがあげられる.

私はこの反論は成り立たないと考えている。 まず，統計的因果推論は集団単位の 因果関係をあつかうというのはその通りだが，だからといって個体レベルの因果を 無視しているわけではない。個体レベルの因果効果のあり方も間接的に推測できる し, 何よりも 5 節の解説で述べたように, 個体レベルの因果が多様だからこそ, 集 団単位の因果効果を具体的なデータからそのままでは求められない.

逆にいえば，もし個体レベルの因果の多様性がなければ，「他の先行変数 $(=$ 共変 量）は全て同一」だといえる. その場合，データから平均因果効果がただちに計算 でき，かつそれはそのまま個体レベルの因果効果でもある，つまり個体レベルの同 質性を仮定するなら, そもそも統計的因果推論は要らない2).

また，集団単位の因果効果の同定はそれ自体で大きな意味がある。近代社会では， 福祉や支援などの政策的介入は必ず集団単位になるからだ（Luhmann 1975）。具 体的にいえば，「一定の基準にあてはまれば全て」という形で実施せざるをえない. だからこそ, 判定基準の妥当性も一般的な形で確保する必要がある ( $\Rightarrow 3$ 節). た 
だたんに知ることをこえて, 社会科学の知識の実践的な意義を主張するならば，ほ とんどの場合, 集団単位での効果の見積もりや測定の形をとるしかない.

つまり，現実には集団単位での特性だけで議論するしかない，あるいは，そうし た方がよい事象や課題が現代の社会には多い. その際の最も適切な測り方は何か, それにどうすれば近づけられるのかも, 統計的因果推論の平均因果効果は示してい るのである.

次に, 統計的因果推論があてはまらない因果があるのかに関しては, もし個体レ ベルで特定の因果を天下り的に前提しないのであれば，具体的なデータから因果を 推定するしかない，その場合，あのI と II の問題を解決する必要がある。具体的な デー夕には必ず複数の個体がふくまれるからである。 そこで統計的因果推論と同じ 問題にぶつかる．例えば，禁欲的プロテスタンティズムの信仰と資本主義的経営と の因果でも，事例を集めて検証しょうとすれば，同じことになる．

言い換えれば, 社会科学であれ自然科学であれ, 因果が作用する基本単位だと想 定されているものは，全て統計的因果推論の「個体」にあたる，人間でも細胞でも 集団でも地球でもかまわない. 例えば, デー夕の散らばりも何らかの因果の形で説 明しようとすれば, やはり個体レべルでの因果を仮説し, それが集団単位でどう現 れるか，という形で考えざるをえない，そこで標準的な定義とは別の因果概念をも ちだすのは, 科学的な研究にとっては有害なだけだ。「結果の原因」や「生成メカ ニズム」の議論は別の形で活かすべきだろう（8 節参照）.

「因果推論の根本問題」はそういう問題なのである.

ただたんに個体レベルの因果が直接観察できないだけでなく，それらが観察でき ないがゆえに，集団単位の因果の同定も，何らかの仮定を天下り的に導入して初め て可能になる。調查観察データであれば,「他の先行変数は全て同一」という条件 を現実にみたすことはむずかしい，実験データで無作為割当てした場合であれば， 測れるのはあくまでも被験者集団限りの期待值である. その被験者集団が本当に知 りたい集団をどこまで代表できているのかを適切に見積もることは，調査観察デー 夕の場合よりもむしろむずかしい（9節および注 5 も参照）.

もちろん, だからといって個体レベルや集団単位の因果的記述ができないわけで

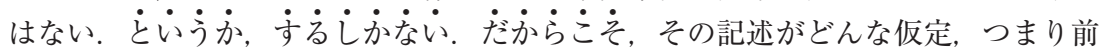
提負荷をともなうかには反省的でなければならない. 統計的因果推論は, 「潜在的 な結果変数 potential outcomes」（5 節の例でいえば(1)～(4)）と原因候補と全ての共 変量の同時分布を想定することで（星野 2009: 42）, 個体レベルの因果と集団単位 の平均因果効果と具体的な測定デー夕の間の関係性を論理的に解明し, その負荷の 見積もり方を示した，そういう形で, 社会科学が何をどこまで知りうるのかの限界 を明確にした。

N. ルーマンの等価機能主義に関連して私自身も述べたことがあるが（佐藤 2011: 287-9), 社会科学の研究で因果と無関連なものは少ない. ウェーバーが「説 明的理解」で述べたように (8 節参照),「意味」や「意味の理解」のなかにも因果 
の命題がふくまれる. それこそ記述統計学的なデータの概観をのぞけば, 社会科学 での記述の多くは因果をふくんでおり, 単一事例の研究でも反事実的命題を使って 因果を特定している（Weber 1906：287=1965: 207-8）.

J. パールも解説しているように (Pearl 2000=2009), 20 世紀前半の数理統計学 や科学哲学は因果の概念自体を方法論的に排除しようとしたが, 現在ではむしろ, 科学的な言明は因果的な記述にならざるをえないと考えられている. そういう意味 で, 統計的因果推論は基本的な考え方で従来の方法と同じであり, だからこそ, 従 来の方法の使い方に反省を迫る。「因果推論の 2 つの大きな潮流として, 統計的因 果推論と質的比較分析がある. しばしば対立的に捉えられる 2 つアアプローチであ るが……, 因果推論の根本問題……理解はいずれにとっても本質的である」（杉 野 2017: 217).

\section{8 社会科学にとっての因果推論}

さらにより一般的にみれば, 統計的因果推論は数理的には, 特定の集団での, 個 体レベルでの条件付き確率の差の期待值 $\mathbf{E}[\mathbf{P}(\mathbf{E} \mid \mathbf{C})-\mathbf{P}(\mathbf{E} \mid \neg \mathbf{C})]$ を測定する。 これ は例えば言葉 C と言葉 $\mathrm{E}$ の意味の関連性にもあてはまる。もし関連があれば,

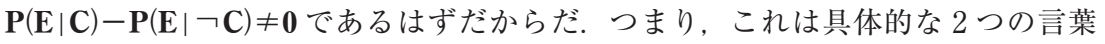
の間に意味ある関係 relevance があるかどうかを, 未知の変数もふくめて全ての先 行変数群を考慮しながら判定する手法でもあり, 集団単位の期待值でそれを測る条 件と手段を示す ${ }^{3)}$.

裏返せば, $\mathbf{E}[\mathbf{P}(\mathbf{E} \mid \mathbf{C})-\mathbf{P}(\mathbf{E} \mid \neg \mathbf{C})] \neq \mathbf{0}$ という統計学的な事実は, 特定の反事実的 因果や意味連関が成立する必要条件であって $(\Rightarrow 4$ 節)，必要十分条件ではない. $\mathrm{E}$ と C の関係性がどんな因果なのか, あるいはどんな意味連関なのかは, 別の知 識や仮定をもちこんで初めて特定できる.だから, 因果は統計学的な事実には還元 できないが, だからといって別の因果定義があるわけではない. 社会科学的な因果 は, (1) 平均因果効果 $\neq 0$ などの統計学的な事実と, (2) 社会科学の知識による解 釈または説明可能性市両方を要件とする.

いうまでもなく，これも「因果的な解明 kausal Deutung」は「因果適合的」か つ「意味適合的」である必要がある，としたウェーバーの考え方の延長上にある （Weber 1921：159=1987：17-8）。「社会学の基礎概念」で，ウェーバーは社会学を 「社会的行為を解明しつつ理解し, これによってその経過とその影響を因果的に説 明しょうとする，一つの科学」だと定義した（Weber 1921：149=1987：6-7). 記 述と説明を区別せず, 理解もふくめて, 因果的記述として位置づけた. 現在の科学 的方法論からみれば, それで正しかったのではないか.

それゆえ, 社会科学の対象で統計的因果推論の例外になるものはほとんどない. 例えば「多様性」や「意味」に注目するアプローチは, 社会学を経済学から差異化 する戦略としては有効であり, 私自身もよく使うが (佐藤 2000), これらも例外に 
はならない.

社会学と経済学のちがいでいえば, たしかに社会学の方が経済学よりも, より多 くの種類の因果関係をより広い範囲で想定する. その分, より複雑な因果関係を視 野にいれているが，あつかう因果関係が複雑であればあるほど，なおさら一つひと つの因果をより厳密に特定する必要がある。「複合的な要因」や「因果の絡みあい」 を想定する場合でも同じだ。つまり，このアプローチを使う際には，少なくとも自 分の分析での因果特定や効果の測り方がどの程度まで適切か, 自分の因果的記述が どんな仮定を置いているのかに関して, より慎重で反省的な検討が求められる. 統 計的因果推論はその有力な手段になる.

実験系の科学や経済学では, 因果推論の主な用途は因果効果量の正確な測定にあ る. そのため, 解説書の事例でも因果関係自体は自明なケースが多い.けれども, 因果推論が本来，疑似的でない原因を識別同定する手法であることを考えれば，社 会学や政策運営などではむしろ, 自明でない实果関倸の識別之具体的な特定を試行 錯誤で進めていく：そちらの方が主な用途になるだろう。こちらの使い方では， 各変数に関する事前の幅広い社会科学的な知識が欠かせない. また共変量になりう る原因候補の変数群だけでなく, 因果の内容の特定に使える媒介変数候補も複数, 調査票にもりこんでおく，などの工夫も重要になる.

それゆえ,「結果の原因」や「生成メカニズム」の議論も, (1) とは異なる因果 基準の探究ではなく，(2) でのより適切な解釈をめざすものとして位置づけ直した 方がよい. この意味での因果効果の解釈は, 統計的因果推論のモデルでいえば, 経 路の複数性（多様性）にあたる. 因果の内容を特定するには, 原因候補 C と結果 $\mathrm{E} の$ 間に複数の経路を想定して識別できればよいからだ。こうした経路の特定は, 調查した集団とはちがう集団に分析結果を適用できるかどうかを判断する際にも, 大きな手がかりになる.

くり返しになるが, 個体レベルはもちろん, 集団単位であっても, 具体的な因果 は何らかの仮定を天下り的に置くことでしか特定できない ( $\Rightarrow 6$ 節). 統計的因果 推論はそれらを解消する方法を教えてくれるが，それにも一定の仮定が必要になる. それでも，測らないよりは測ってみた方がよい，あるいは，因果の特定にはどんな 条件群をみたす必要があるのかを正確に理解した上で, 自分が主張している因果的 記述はそれらをどの程度仮定でおぎなっているかを，反省的にあつかえた方が望ま しい.

例えば，因果の特定の手段としてみた場合，重回帰は不完全な因果推論にあたる ( $\Rightarrow 5$ 節)。忞方点でし完ば，重回帰分析も単一事例研究もともに不完全な因果推論 であり，両者の間に絶対的な優劣があるわけではない. 因果推論としては，反省的 でない重回帰よりも，反省的な事例研究の方が厳密な方法でありうる. 


\section{9 「質の良い」データの重要性}

統計的因果推論は, デー夕の集め方にも関わってくる. 実はこの点でも基本的な 考え方は従来と変わらない. むしろ, 統計的因果推論によって厳密な因果同定がで きるようになって，「質の良い」データの意義も飛躍的に高まった，そう考えた方 がよい.

特に重要なのは「独立性」の条件だ。これは簡単にいえば,「cであるか c でな いかによって, 潜在的な結果変数の観察のされ方が影響されない」ことであり, デ 一夕から平均因果効果を計算できる必要条件の 1 つである ${ }^{4)}$. 5 節の例でいえば， $\mathrm{c}$ であるかどうかによって，(1)〜(4)の 4 種類の個体レベルの因果が観察にふくまれる 可能性が影響されないことにあたる.

いうまでもなく，この条件を守ることはきわめてむずかしい. 同じく必要条件で ある測定対象の規模とはちがい, そもそも個体レべルでは「cである」と「cでな い」のどちらかは反事実であり, 直接確認できない, それゆえ, デー夕の収集過程 で工夫するしかない.

例えば，「Cと Eの間に因果がある」という仮説をもっていると，(1)やた反例 にあたる(4)には注意をむけやすいが，(2)や(3)の可能性には考えが及びにくい，(2)や (3)，Cがどうだろうとそもそも結果に影響しないというあり方であり，Cの重要 性それ自体を否定するものだからだそそれゆえ，個々の「eである」あるいは「e でない」の事例が(1)や(4)でなく, (2)や(3)である可能性を十分に検討するためには, 自分自身の仮説を一段メ夕の視点で, それもいわばゼロ・ベースで反省できる冷静 さが求められる.

そういう意味でも, デー夕の収集過程は重要なものになる. デー夕の集め方こそ が，因果に注目する研究の成否を決定的に左右する，統計的因果推論はそのことも， 従来の数理モデルょり一段高い水準で, より強烈に教えてくれる.

これはそのまま「デー夕科学」の限界にも利点にもなる ( $\Rightarrow 2$ 節). 一方で, ネ ット上での呟きなど, 注目する結果だけにもとづいて集められた（a）型のデー夕 は，代表性もなく，独立性条件も守られない，さらに先行変数の情報もほとんどな いので，そもそも因果を論じる参考にはならない，他方で，例えば広範囲なテキス トが全数デジタル化されるなど, 特定の仮説との関連が弱いことを証明できる形で データが収集されれば，因果を識別する上で有力な手段になる.

「意味」についても同じことがいえる ( $\Rightarrow 8$ 節)，この場合, 特定の「意味」を前 提にしてテキストを調べる作業自体が，やはり独立性条件を守りにくくする.

したがって, 因果にせよ意味連関にせよ, 独立性条件を守りやすくするには, 未 知の先行変数を発見しやすい形で, ふだんの研究も進めておく工夫が欠かせない. 例えば，ジャンルにせよ時代にせよ社会にせよ，自分の研究対象にあたる区分より も意図的に一段広い範囲で, 資料や他の研究や調查に目を配っておく（（２節). 
未知の先行変数を最も発見しやすいのは，そこだと考えられるからだ.

特に反省的な事例研究にとって, そうした研究戦略は不可避だろうが, これは共 変量が自明でない場合に, 計量的な分析が進むべき方向でもある（星野 2009: 129, 136-42). さらに, 因果推論の結果を政策的介入の判断材料に使う際にも, 調查さ れた集団が介入予定の集団をどれだけ代表できるのかを，より良く調べられるよう になる。

まとめていえば，反事実的因果を代理測定できる要件を統計的因果推論は明確に した. (1)実際に測れるのは特定の集団での平均因果効果であり，かつ(2)測定条件を 完全にみたせることは，社会科学ではきわめて少ない，実験デー夕なら被験者集団 の代表性, 調査観察デー夕なら共変量の網羅性を, 実際には仮定せざるをえない. けれども，(3)集団単位にせよ個体レベルにせよ，因果や意味連関を識別する方法的 な基準としてはこれが最も適切であり, かつ(4)社会科学の記述や説明の多くは因果 か，それと同等な何かを前提にしている.

ならば，できる範囲で，できる限り，良い測り方をめざせばよい．社会科学的な 因果の特定に打いて, 完全な形での使用がごく限ら礼方之方意味で, 統計因果推 論もまた不完全な手法である。だとすれば，重回帰などの従来の要因分析の手法も， 統計的因果推論に対抗するものとしてではなく, 確証型／探索型のように相補的に 使えばよい。

例えば，代表性を確保するために複数の被験者集団で同一の社会実験をした場合 に，もし実験の結果に何らかのちがいが生じれば，統計的因果推論の論理上，その 理由は「被験者集団がちがう」以外にはありえない。つまり，そこには，被験者集 団同士のちがいと相関の高い何かの変数が, 無作為化されていない重要な共変量と して潜んでいる ${ }^{5)}$ ，その解明は，従来型の調査と計量手法を用いて探索的に進める しかない.

\section{0 ベイズ統計学と理解社会学}

もはや本格的に議論する余裕はないが, 統計的因果推論と並んでもう 1つ, 自然 科学と社会科学に分化する以前にうまれ, 自然科学のなかで数理的に形式化されて 広く使われるようになり，その形で社会科学にも導入されつつある方法がある。 べ イズ統計学である.

統計学のさまざまな分野で, 現在, ベイズ統計学の考え方は従来の頻度主義と入 れ替わる形で渗透しつつある。例えば 3 節で区間推定が第一選択になりつつあると 述べたが, その場合も，母数をべイズ統計学的にあつかっている.

私の考えでは, ベイズ統計学の枠組みは特に意味の理解の定式化に適している. 統計的因果推論がウェーバーの適合的因果を数理の形で明確化したように, ベイズ 統計学はウェーバーの理解社会学を数理的な形で明確にしてくれる. ただし，これ はまだかなり私の独自な発想によるもので, 統計的因果推論のように, ある程度確 
立された知識として述べるのは適切ではない. 詳しくは佐藤（2018）を読んでほし w.

その点を断った上で, 簡単にふれておくと, ベイズ統計学はベイズの定理,

$$
\mathbf{P}(\boldsymbol{\theta} \mid \mathbf{d})=\frac{\mathbf{P}(\boldsymbol{\theta})}{\mathbf{P}(\mathbf{d})} \mathbf{P}(\mathbf{d} \mid \boldsymbol{\theta})
$$

にもとづく， $\theta$ は直接観察できない母数, $\mathrm{d}$ は外的に観察できるデー夕を示す.

実はこの定理は社会調査法でも必ず出てくる. 特定の母数の值 $\theta$ からデータ $\mathrm{d}$ が出現する確率 $(=\mathbf{P}(\mathbf{d} \mid \boldsymbol{\theta}))$ と, データ $\mathrm{d}$ から推定された值 $\theta$ が正しい確率（= $\mathbf{P}(\boldsymbol{\theta} \mid \mathbf{d}))$ は同じではない. 有意確率（p 值）は前者にあたる. 後者を知りたければ, 前者だけでなく, $\mathbf{P}(\boldsymbol{\theta}) / \mathbf{P}(\mathbf{d})$ も知る必要がある。これは一般的には未知であり, 何 らかの仮定を置いて推測するしかない.

つまりべイズの定理は, 観察されるデータから観察できない母数を推論する操作 であり, それゆえ, 観察される行為の外形 $\mathrm{d}$ から, 直接観察できない行為の意味 $\theta$ を推論する操作にもあてはまる。実際, 裁判の立証過程の分析では 1970 年代から 使われており，例えば太田（1987）はこの定理を用いて，不確実性をふまえた法的 判断の形成をあざやかに再構成している.

やはりウェーバーの理解社会学に関連づけると, ウェーバーは因果的記述の形を とる「説明的理解」だけでなく,「2×2=4」のような「直接的理解」も, 多数の 観察データにもとづく近似的な推論だとしている（Weber 1918：531=1980: 109 など). 推論である以上, つねに不確実性がともなう。裏返せば，一定の仮定を置 いて不確実性を仮想的に消すことで, 具体的な理解は成立する（詳しくは佐藤 2018 を参照).

だとすれば，理解社会学もまた，前提仮説とデータにもとづく推論であり，ベイ ズ統計学の枠組みを使って定式化できる．ベイズ統計学が「事後分布 $=$ 事前分布 + データの情報」と表現されるように, 理解社会学にはつねに（「事前分布」にあた る）主観的な部分と（「データの情報」にあたる）客観的な部分がある.その両面 をもつ方法として, 論理的に定式化できる，それによって，行為の意味の解釈度を 変数としてあつかえる ${ }^{6)}$.

例えば，強い前提仮説がある場合には，データ群から客観的な情報があたえられ ていても, 前提仮説にかなり近い形で行為の意味は理解される。けれども，だから といって, デー夕群の情報も客観的ではないと考える必要はない. また, それらの 情報は程度の差はあれ, 必ず理解に反映される。一そそうた形で, 主観的な部分 と客観的な部分がつねに並存する形の演算として, 理解社会学をモデル化できる.

\section{1 主観的かつ客観的な「社会」}

では, これらの方法の考察から, 社会について何がいえるだろうか. 最後に簡単 
に述べておこう.

もし統計的因果推論による適合的因果の再定式化や，ベイズ統計学の枠組みによ る理解社会学の再定式化が妥当なものだとすれば, 因果的記述も意味の理解も，一 定の仮定を前提にして初めて成立する。したがって，これらが社会科学の基本的な 方法であるとすれば, 社会科学がとらえている「社会」もつねに一定の仮定をふく んでいる.

その意味で，社会は real であるとともに imaginary でもある．別の言い方をす れば，社会科学には純粋な客観性は存在しないが, 同じ意味で, 純粋な主観性も存 在しない.「社会学とは社会的行為を解明しつつ理解し, これによってその経過と その影響を因果的に説明しようとする，一つの科学」というウェーバーの定義（ 8 節）は, その点でも的確なものだと思う.

因果の特定でいえば，「cである/でない」「eである/でない」自体は直接観察 される, というだけではない. 独立性などの条件群がみたされれば, 経験的な手段 だけで, 他の変数が原因である可能性を全て排除できる。それを論証することで, 統計的因果推論は因果を理論上は実在的なもの, 他ではありえないものにした. ベ イズ統計学的な意味の理解でいえば, 行為の外形にあたるデー夕はやはり直接に観 察される. それらの点では全く realである.

けれども, それによって imaginary な部分が消えるわけではない. 因果の特定 も意味の理解も実際には推論になる，すなわち，現実には一定の仮定を前提に置い て，初めて特定できる．因果の特定でいえば，例えば，独立性条件をみたしていな い観察による因果の記述や説明は全て，何らかの仮定にもとづくといわざるをえな い. 統計的因果推論はそれも同時に論証した，意味の理解でいえば，事前分布にあ たる仮説を置かなければ, データから事後分布を特定できない.

もちろん, 経験的な研究を積み重ねて, より妥当な仮定へ改良することはできる. 効果量の分析のような手法はそこでも役立つだろうが，それで仮定を解消できるわ けではない. その意味で, ここでいう「imaginary な部分」は当事者の理念や夢や 願望ではない，当事者というょりも，当事者が観察する場合もふくめて，観察者の 観察相関的に成立する。例えば，もし社会を因果的なメカニズムとして考えれば, 特定された因果の束が社会の本体にあたるが，その個々の因果の具体的な同定はつ ねに仮定をふくんでいる。それが「imaginary な部分」だ.

盛山和夫も同じことを指摘していたと思うが（盛山 2013）, 私自身はこれを「社 会科学では主観性と客観性がつねに両立する」という形で考えている，その意味で， 「事実か解釈か」という二者択一は誤っている. あえて比喻的に表現すれば, 観察 される社会にはつねに事実と解釈が交じりあっている. 統計的因果推論やベイズ統 計学は, この 2 つがどのように交じりあっているのかを, 従来よりも明確かつ一貫 した形で見せてくれる.

したがって, 比喻的な表現ではなく, 㛜密な意味において, 社会を実定的に記述 し説明しようとする営みそれ自体が，記述され説明される社会に実定性をあたえる. 
観察する社会科学が主観的 assumptive かつ客観的 factual であることによって, 観察される社会もまた, 客観的 objective かつ主観的 subjective なものでありつづ ける。

現在の社会科学が経験しつつある新たな方法の普及は，たんなる技術的な改良で はない．従来の方法を数理的な定式化を通じてより明確な形へ更新するものであり， それによって社会科学の方法はどんな性格のもので, 社会科学が対象とし主題化し てきた社会とはどんなものなのかを，より明確にしてくれる.

その意味で, 社会科学の方法とは社会の理論だといえるかもしれない.

[付記］この論考は日本学術振興会科学研究費助成（基盤研究 C)「ベイズ統計学的枠組みによ る理解社会学と意味システム論の再構築」の成果の一部である.

\section{[注]}

1）J. ゴールドソープの「因果, 統計, 社会学」(Goldthorpe 2007a の第 9 章など) はおそらく この点で誤解している，そのため代理測定であることに実質的に気づいているが，その意味を 取り違えており，統計的因果推論が反事実的因果定義にもとづくことも無視している。また， 「社会学と確率革命」(Goldthorpe 2007b の第 8 章など) のウェーバー論でも, 適合的因果での (1)反事実的命題の重要さと (2) v. クリースからの影響を指摘した Ringer（1997）に言及しなが ら，(1)にも(2)にも全く触れずに，W.レキシスとの関係だけをとりあげている，note38などは， 率直にいって異様な感じすらする.

「説明的理解」の位置づけなど, 他の論点では同意見のものが少なくないのだが, 因果推論 に関連する部分では以降で述べるように，方法論でも学説史でも系統的な誤読が生じている. 近著の Goldthorpe（2016：104-11）では, ウェーバーが反事実的因果定義を用いていることは 認めているが, 統計的因果推論への批判の内容は変わっていない. なお, Morgan \& Winship (2015：438-46）も参照.

2）筒井（2017）はこの点で誤解していると思う。また「個体特性を除去した」「同質性を作り 出す」(筒井 2017: 169,171) などの表現が統計的因果推論の数理のどこを指すのか, 私には理 解できなかった。

3）意味の場合，ネットワーク状で成立すると考えれば，厳密な効果の同定は必要ないが，例え ば，言葉 C と E が多義的で，かつその意味がそれぞれ独自の文脈依存性によると考えれば，統 計的因果推論と同じ状沉になる.

4）厳密な定義は星野（2009：43-5）や岩崎（2015：82-9）を参照.

5）その意味で, 実験デー夕での被験者集団の代表性の仮定と, 調查観察デー夕での共変量の網 羅性の仮定は, 同じものである.

6）この点で, 佐藤（2018）は北田（2017）への回答にもなっていると考えている.「解釈主義」 という呼び名が方法論的検討に役立つとは思わないが，少なくとも私自身は「事実か解釈か」 は二者択一ではないと考えており, 解釈主義でも, 反解釈主義でも, 非解釈主義でもないと思 う.

\section{[文献]}

遠藤知巳, 2006,「言説分析とその困難 (改訂版)」佐藤俊樹・友枝敏雄編『言説分析の可能性— 
社会学的方法の迷宮から』東信堂, 27-58.

Goldthorpe, John, 2007a, On Sociology, 2 ed., vol. 1: Critique and Program, Stanford: Stanford University Press.

—, 2007b, On Sociology, 2 ed., vol. 2: Illustration and Retrospect, Stanford: Stanford

University Press.

—, 2016, Sociology as a Population Science, Cambridge: Cambridge University Press.

南風原朝和, 2014, 『続・心理統計学の基礎——統合的理解を広げ深める』有斐閣.

橋本摂子, 2014, 「不正を理解すること一一原発事故と『復興』をめぐる一考察」『現代社会学理論

研究』8: 14-25.

Holland, Paul W., 1986, "Statistics and Causal Inference," Journal of the American Statistical Association, 81: 945-60.

星野崇宏, 2009, 『調查観察データの統計科学——因果推論・選択バイアス・デー夕融合』岩波書 店.

石田浩, 2012,「社会科学における因果推論の可能性」『理論と方法』27(1)：1-18.

岩崎学, 2015, 『統計的因果推論』朝倉書店.

北田暁大, 2017,「他者論のルーマン——経験的学としての社会システム理論」『現代思想』45(6)： $202-19$.

Luhmann, Niklas, 1975, "Formen des Helfens im Wandel gesellschaftlicher Bedingungen,"

Soziologische Aufklärung 2, Opladen, Westdeutscher, 134-49.

Morgan, Stephen and Christopher Winship, 2015, Counterfactuals and Causal Inference: Methods and

Principles for Social Research, 2 ed., New York: Cambridge University Press.

永田靖, 2003, 『サンプルサイズの決め方』朝倉書店.

中澤涉, 2017, 「地位達成の因果的推論」日本社会学会社会学理論応用事典刊行委員会編『社会学

理論応用事典』丸善出版, 458-9.

太田勝造, 1987, 『裁判における証明論の基礎——事実認定と証明責任のベイズ論的構成』弘文堂.

Pearl, Judea, 2000, Causality: Models, Reasoning, and Inference, New York: Cambridge University

Press. (=2009, 黒木学訳『統計的因果推論——モデル・推論・推測』共立出版.)

Ringer, Fritz, 1997, Max Weber's Methodology: the Unification of the Cultural and Social Sciences,

Cambridge: Harvard University Press.

佐藤俊樹, 2000,「統計の実践的意味を考える——計量分析のエスノメソッド」佐伯胖・松原望編 『実践としての統計学』東京大学出版会, 179-212.

—, 2006, 「閾のありか」佐藤俊樹・友枝敏雄編『言説分析の可能性一一社会学的方法の迷 宮から』東信堂, 3-26.

—, 2011, 『社会学の方法——その歴史と構造』ミネルヴァ書房.

——, 2016, 「世論と世論調查の社会学——『前面化』と『潜在化』の現在と未来」『放送メデ イア研究』13: 309-33.

——, 2017,「ウェーバーの社会学方法論の生成(5)〜6」『書斎の空』650: 57-64, 651: 51-60.

, 2018,「自己産出系のセマンティクス」佐藤俊樹・立岩真也・若林幹夫編『社会が現れ

るとき』東京大学出版会 (近刊).

盛山和夫, 2013, 『社会学の方法的立場——客観性とは何か』東京大学出版会.

杉野勇, 2017, 『入門・社会統計学— 2 ステップで基礎から〔Rで〕学ぶ』法律文化社.

戸田山和久, 2005, 『科学哲学の冒険——イエンスの目的と方法をさぐる』日本放送出版協会. 
筒井淳也, 2017, 「数字を使って何をするのか一一計量社会学の行方」『現代思想』45(6)：162-77.

Weber, Max, 1906, “Kritische Studien auf dem Gebiet der kulturwissenschaftlichen Logik," in Weber [1922]1988, 215-90. (=1965, 森岡弘通訳「文化科学の論理学の領域における批判的研 究」『歴史は科学か』みすず書房, 99-227. )

—, 1918, “Der Sinn der »Wertfreiheit « der soziologischen und ökonomischen Wissenschaften,” in Weber [1922]1988, 489-540．（=1980，木本幸造監訳『社会学・経済学における「価值 自由」の意味 (改訂版)』日本評論社. )

— , 1921, "Soziologische Grundbegriffe," MWG1/23 Wirtschaft und Gesellschaft Soziologie, Tübingen: J. C. B. Mohr, 147-215.（=1987，阿閉吉男 · 内藤莞爾訳『社会学の基礎概念』恒星 社厚生閣. )

—, [1922]1988, Gesammelte Aufsätze zur Wissenschaftslehre. Tübingen: J. C. B. Mohr (UTB 1492).

Weiberg, Michael, 2013, Simulation and Similarity: Using Models to Understand the World, Oxford:

Oxford University Press. (=2017, 松王政浩訳『科学とモデル—シミュレーションの哲学入 門』名古屋大学出版会. ) 


\title{
Making Sociological Inferences by Quantifying Data: \\ Society and Social Science Shown by "New" Mathematical Methods
}

\author{
SATO, Toshiki \\ The University of Tokyo \\ tsatou@waka.c.u-tokyo.ac.jp
}

Several recently introduced methods in the social sciences, such as statistical causal inference and Bayesian statistics, have had profound effects on the science of sociology as well as the analysis of effect size. These methods share some fundamental concepts with traditional methods, especially Weber's adequate causation and interpretive sociology, and can be applied not only to numerical data but also to discourse.

For example, statistical causal inference is a method that accurately estimates the average causal effect based on the assumption that causality varies at the individual level. By assuming the joint distribution of potential outcomes, causal candidates, and all covariates, we can define the adequate causation more accurately and consistently. Thus, theoretically, this method can be applied to a one-time-only phenomenon. Additionally, interpretive sociology can be reformulated as a Bayesian update, which modifies subjective and hypothetical assumptions through iterative process applying objective and observable data.

These methods have both factual and assumptive aspects; therefore, the sociological phenomena inferred through these methods also have subjective and objective aspects.

Key words: statistical causal inference, Bayesian statistics, interpretive sociology 